\title{
Intellectual Property Rights and the Canadian Pharmaceutial marketplace: Where Do We Go From Here?
}

\author{
By Joel Lexchin
}




\title{
Intellectual Property Rights and the Canadian Pharmaceutial marketplace: Where Do We Go From Here?
}

\author{
By Joel Lexchin
}

ISBN: 0-88627-348-X

June 2003

\section{About the Author:}

Joel Lexchin, M D , is an Associate Professor at the School of $\mathrm{H}$ ealth Policy and M anagement, Atkinson Faculty of Liberal and Professional Studies at York University. H e is also an Associate Professor at the D epartment of Family and Community M edicine, University of Toronto and a physician at the Department of Emergency M edicine, University H ealth N etwork.

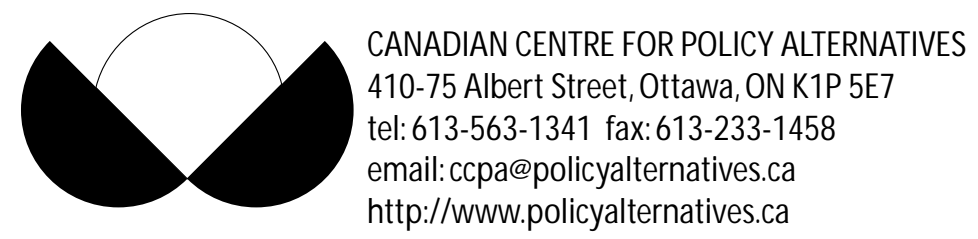




\section{Table of contents}

Executive summary ................................................................................................... 1

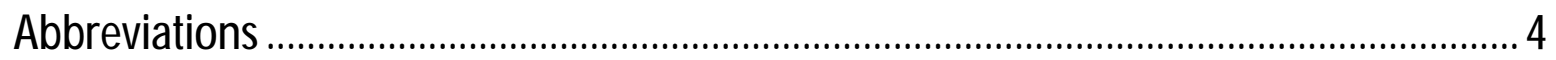

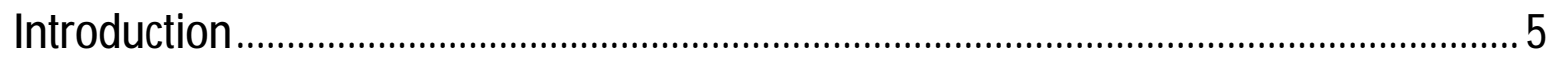

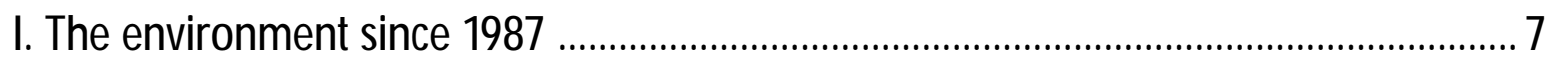

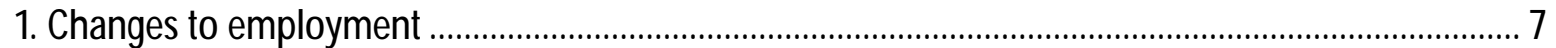

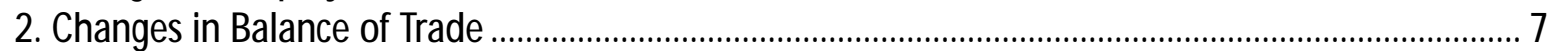

3. Changes in investment in research and development .................................................................... 9

4. Changes in prescription costs and drug spending ..................................................................... 10

II. Industry's argument for expanded IPR protection .................................................. 12

1. Profit levels ........................................................................................................................ 12

2. The value of new drugs .......................................................................................................................... 12

3. The cost of developing new drugs ......................................................................................................... 13

4. How long is the actual monopoly period? ........................................................................................ 14

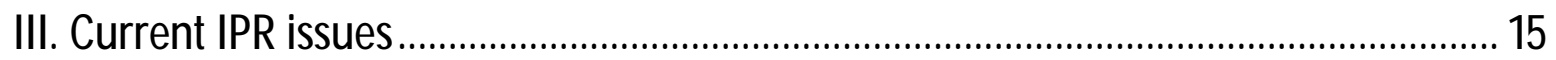

1. Recent rulings by the World Trade Organization (WTO) ..................................................................

2. Further IPR disputes ................................................................................................................ 15

IV. The Free Trade Area of the Americas (FTAA) Agreement ........................................ 19

1. Extension of patent term ......................................................................................................................... 19

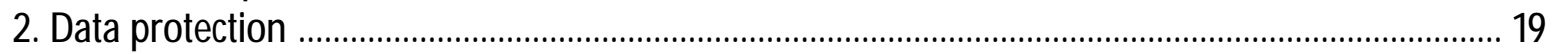

3. Linkage requirements ................................................................................................................ 19

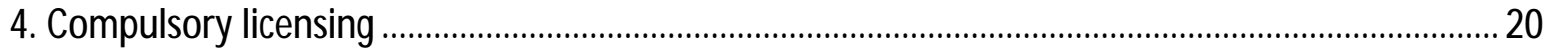

V. How IPRs distort the pharmaceutical marketplace ………………............................. 21

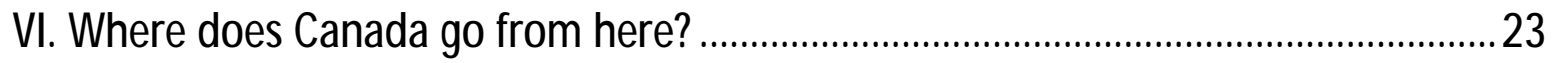

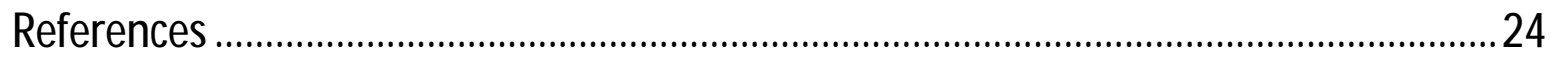





\section{Executive summary}

\section{Introduction}

Patent protection for prescription drugs has a long and contentioushistory in Canada. Between 1969 and 1987 Canada had a system of compulsory licensing which meant that generic copies of brand name drugs could come onto the market within 5 to 7 years after the original drug appeared. Bills C - 22 and C-91, passed as part of C anada's commitment to various trade deals first weakened and then abolished compulsory licensing. N ow the issue of intellectual property rights has returned to the agenda partly as a result of the Romanow Report but al so because drug companies, through their organization C anada's Research-Based Pharmaceutical Companies ( $R \times \& D$ ) are pushing for more patent protection. The H ouse of Commons Industry, Science and Technology Committee is holding hearings on "evergreening," the practice whereby the brand name companies can delay the marketing of generics but there are other significant issues with respect to patent protection.

In order to decide on a future course of action that Canada should take with regard to intellectual property rights (IPRs) it is useful to review downstream effects in $C$ anada that resulted from C-22 and C-91. This paper will examine changes to employment, $C$ anada's balance of trade in pharmaceuticals, investment in research and development and finally drug expenditures. Second, it will review thearguments advanced by the pharmaceutical industry in favour of stronger protection for IPRs. Recently, there have been complaints made against $C$ anada at the W orld Trade O rganization (W TO) regarding pharmaceutical IPR s and these and other contemporary issuesare the subject of the third section. The fourth sec- tion deals with the second draft text agreement of theFreeTrade Area of the Americas which will, if implemented, have significant repercussions on pharmaceutical IPRs. Patents distort the marketplace for drugs in a number of ways and the fifth section will briefly touch on half a dozen of these. Finally, the paper concludes with some alternative recommendations on the future of IPRs.

\section{The environment since 1987}

The multinational companies claim that the liberalization of the patent laws has increased employment in the industry. W hile employment is up compared to 1990, it is also up proportionately more in the generic industry. Although there are more people doing research and development their numbers do not match the number of salespeople the industry employs.

B efore Bill C - 22 was passed in 1987 C anada had a negative balance of trade in pharmaceuticals of $\$ 491$ million, but by 2000 this had ballooned to $\$ 4059$ million. M oreover, imports are becoming a larger and larger part of the $C$ anadian market, so that by 2000 they represented over $75 \%$.

Research and development by the multinationals increased from 1987 to 1997 but has been declining ever since as a percent of total sales. $\mathrm{H}$ ere in $C$ anada, basic research makes up about $16 \%$ of all $R \& D$ compared to $24.5 \%$ in the United Kingdom and $36 \%$ in the United States. Even compared to smaller European countries C anada is behind in $R \& D$ spending.

Although the Patented M edicine Prices Review Board, established in 1987 through Bill C - 
22, has kept the price of individual drugs down, it has donenothing to curb increasing overall drug expenditures. Between 1975 and 1987 spending on prescription medications went from $6.3 \%$ of the health care dollar to $7.0 \%$; since then it has risen to $12.0 \%$.

\section{Industry's argument for expanded IPR protection}

The crux of the industry's argument for stronger intellectual property rights protection is that it needs the time to recoup its investments in order to be able to afford the costs entailed in the re search and development of new drugs, drugs that may bemoreexpensivethan existing ones but are also more effective and/or more safe.

Profit levels in the pharmaceutical industry compared to other "high tech" industries in the mid 1990 s was over $15 \%$ on capital employed compared to $10 \%$ for electronic products and $9 \%$ for telecommunications carriers. D espite what the industry regards as inadequate patent protection it was still highly profitable in Canada.

M ost new drugs do not offer any significant improvement over existing therapies. 0 ut of 455 new patented drugsintroduced into $C$ anada from 1996 to 2000 only 25 were major improvements or breakthroughs.

A recent study reports that it costs over US $\$ 800$ million to develop a single new drug but there are reasons to doubt that figure. It excludes drugs that are combinations of previously available medications and reformulations of existing products (e.g., new dosage forms) and drugs developed with funding from nonindustry sources such as government, hospitals, foundations or medical schools. Public Citizen Congress Watch, an American consumer group, looked at an earlier figure of US $\$ 500$ million to develop a new drug and recalculated that the amount should

2 Canadian Centre for Policy Alternatives actually only beU $S \$ 110$ million in out-of-pocket costs.

Finally, we don't have accurate figures about how long drug companies have monopolies before generics enter themarket. $R \times \& D$ claims that it is 10 years but it could be up to almost 2 years longer.

\section{Current IPR issues}

There have been two separate complaints against Canada at theWorld TradeO rganization (WTO) in the past few years. As a result of those complaints $\mathrm{C}$ anada had to pass legislation that will give 30 drugs extra patent protection resulting in an extra $\$ 40$ million in drug costs and that will delay the entry of generic products.

Industry organizations in Canada and the United States are still unhappy with Canadian IPRs. They claim that we do not give adequate protection to the safety datathat the multinational companies develop and let the generic companies use this data, which is contrary to the rules of the WTO. Their other major criticism is that we are not enforcing the $\mathrm{N}$ otice of Compliance (N O C) "Linkage" Regulations sufficiently strongly. The linkage regulations stop $C$ anada from allowing a generic drug on the market until it can show that it has not violated any of the brand name manufacturer's patents. In the U nited States where a similar rule exists, President Bush has recently announced that hewill limit themultinational companies ability to usethis rule because the companies have been abusing it.

\section{The Free Trade Area of the Americas (FTAA) Agreement}

TheFTAA is an agreement that if negotiated will set up a free trade area covering every country in $N$ orth, $C$ entral and South America and the $\mathrm{Car}$ ibbean except $\mathrm{Cuba}$. If passed in its current form 
it could have serious repercussions on drug patents in $\mathrm{C}$ anada. It could result in longer patent terms to make up for regulatory delays in granting patents and approving new drugs, despite a WTO ruling that this is not a "legitimate interest" within themeaning of theT RIPS agreement. Rules around data protection will be hardened limiting the ability of generic companies to use this type of information. The equivalent of the N O C Linkage Regulations would bewritten into the agreement meaning that if $C$ anada every wanted to change these rules it would need to reopen the entire FTAA agreement. Finally, although $C$ anada currently does not use compulsory licensing for drugs, the FTAA would make it much more difficult for $\mathrm{C}$ anada to change its mind in the future.

\section{How IRPs distort the pharmaceutical marketplace}

The large majority of drugs produced through research led by the patent incentive do not represent any significant therapeutic advances. Industry largely engages in $R \& D$ of products that are aimed at carving out a share of a lucrative market. Since most drugs offer little or no therapeutic advantage over existing remediesthen it stands to reason that most of the money spent on $R \& D$ is going into products that will build market share not products that will necessarily result in significantly better health outcomes. In order to capture market share drug companies spend about $\$ 1.7$ billion on drug promotion in Canada and more than ten times that amount in the U.S. G aining a competitive edge on rival firms leads to a restriction in sharing of research results and delays in publication of findings because of commercial concerns. Communication isthelifeblood of science and if it is impeded so is scientific re search. W ithout knowing what others are doing scientists may be needlessly repeating work. D rug companies spend millions in legal costs filing and protecting patents and in lobbying fees to make sure that politicians know the industry's point of view. In $\mathrm{C}$ anada, industry supporters such as D eputy-PrimeM inister John M anley receivetens of thousands of dollars in contributionsfrom drug companies. Large sums are also spent supporting consumer and patient groups which then appear to speak with an independent voice in support of industry positions.

\section{Where does Canada go from here?}

If we accept the argument that intellectual property rights are necessary for the development of new pharmaceuticals then the question becomes how much patent time is required to ensure that companies continue to invest in new drug $R \& D$. Theonly attempt to have an independent look at the drug industry's books to determine this figure was thwarted in the U.S. Supreme Court. Therefore, we are forced to rely on self-reported numbers from the industry.

A more fundamental question is whether or not the patent system is even necessary. A recent American study argued that at a certain point it becomes less expensive to fund $R \& D$ from public sources rather than continuing to rely on the patent system and private enterprise. The extra public funds that would be required would be more than made up for in savings on drug costs. These numbers comefrom the American context and may or may not apply equally well in C anada but they should serve to start a debate about whether or not the patent system is the best way to fund pharmaceutical $R \& D$. 


\section{Abbreviations}

$\begin{array}{ll}\text { BMS } & \text { Bristol-M yers Squibb } \\ \text { CCOHTA } & \text { Canadian Coordinating O ffice for Health Technology Assessment } \\ \text { CGPA } & \text { Canadian Generic Pharmaceutical Association } \\ \text { EU } & \text { European Union } \\ \text { FTA } & \text { FreeTrade Agreement } \\ \text { FTAA } & \text { FreeTrade Area of the Americas } \\ \text { IPR } & \text { Intellectual property rights } \\ \text { NAFTA } & \text { N orth American FreeTrade Agreement } \\ \text { NOA } & \text { N otice of Allegation } \\ \text { NOC } & \text { N otice of Compliance } \\ \text { PhRMA } & \text { Pharmaceutical Research and M anufacturers of America } \\ \text { PMPRB } & \text { Patented M edicine Prices Review Board } \\ \text { R\&D } & \text { Research and development } \\ \text { RX\&D } & \text { Canada's Research-Based Pharmaceutical Companies } \\ \text { TRIPS } & \text { Trade Related Aspects of Intellectual Property Rights } \\ \text { USTR } & \text { United States Trade Representative } \\ \text { WTO } & \text { World Trade O rganization }\end{array}$




\section{Introduction}

Intellectual property rights (IPR) and patent issues are key factors in determining how much individual drugs cost and the overall level of expenditure on drugs. In the 1980s and 1990s Canada first limited compulsory licensing for pharmaceuticals (Bill C-22) and then abolished it (Bill C-91). Since Bill C-91 was passed there has been a review of the patent legislation in 1997. That review reaffirmed $C$ anada's commitment to a 20 year patent period but made no concrete recommendations for any reforms or changes in the patent system. ${ }^{1}$

The recently released report of the Commission on the Future of $\mathrm{H}$ ealth $\mathrm{C}$ are in $\mathrm{C}$ anada (Romanow Report) once again rai sed the issue of pharmaceutical patents. ${ }^{2}$ Romanow was critical of the practice of "evergreening," "where manufacturers of brand name drugs make variations to existing drugsin order to extend their patent coverage. This delays the ability of generic manufacturers to develop cheaper products for the marketplace and it is a questionable outcome of $C$ anada's patent law. Furthermore, regulations under the patent law require generic drug manufacturers to demonstrate that their product is not infringing on a patent held by another drug manufacturer rather than putting the onus on the patent drug manufacturer to show that their patent has been infringed - what is referred to as the notice of compliance regulations. Suggestions have been made that this leads to "pre-emptory" lawsuits from patented drug manufacturers as a way of delaying the approval of generic drugs." Romanow recommended that the federal government examine theissue of the "what constitutes a legitimate extension of patent protection."
The Liberal government is extremely reluctant to tackletheissue of drug patents. M orethan a dozen Liberal cabinet minister staffers and Liberal campaign strategists areworking on behalf of multinational pharmaceutical companies. ${ }^{3}$ In 0 ctober 2001, Brian Tobin, then Industry M inister, wrote in a letter to the Canadian D rug $M$ anufacturers Association (now the Canadian Generic Pharmaceutical Association), the generics lobby group, that the government was committed to keeping patent laws "among the most modern and progressive in the world." $\mathrm{He}$ did not repeat a past promise to revisit the regulations, and instead offered only a noncommittal reassurance: "D epartmental officials will continue to monitor them on an ongoing basis to ensure they are working as intended." After September 11 2001, while Alan Rock was H ealth M inister he defended officials in his M inistry who threatened to use compulsory licensing to acquire sufficient stocks of theantibiotic ciprofloxacin should there be a threat of the release of anthrax by terrorists. H owever after his first cabinet meeting as Industry M inister, Rock affirmed hiscommitment to $C$ anada's patent law, saying it was "there to protect and encourageinnovation and to reward those with new ideas. That's how civilized societies do that, by granting a period of market protection, so people who have innovated can be rewarded." Appearing before the $\mathrm{H}$ ouse of C ommons Standing Committee on Industry, Science and Technology in M ay 2002, Rock repeated his defense of the current patent system. ${ }^{4}$

In June 2002, the Industry, Science and Technology Committee voted to review the use of "evergreening" tactics by the pharmaceutical industry. Initially the review wasto begin following 
the summer 2002 parliamentary recess. ${ }^{5} 0$ pponents of the review pushed the item down the committee's agenda and finally in A pril 2003, two Liberal members of parliament were allegedly brought in as alternate committee members and voted to postpone the review to late June 2003 by which timethe $\mathrm{H}$ ouse of $\mathrm{Commons}$ was likely to have recessed for the summer. ${ }^{6}$ This decision was later reversed, likely as a result of adverse publicity. The committee has decided to only hear testimony from government officials and representatives of the brand name and generic drug industries. TheClerk of the committee explained, in a letter, that this decision to restrict the hearings was the result of the "narrow scope of the inquiry" and the "committee's very full schedule." (Jean François Pagé, personal communication, $M$ ay 20, 2003). O thers believe that the reason that other people are not being heard is a desire on the Liberal government's part to makesurethat wider issues around pharmaceutical patents are not brought up.

Romanow's report and the committee hearings are only addressing one of the many contemporary debates in $\mathrm{C}$ anada around intellectual property rights and patent protection. Canada's Research-Based Pharmaceutical Companies $(R \times \& D)$, the organization representing the multinational companies with subsidiaries in $\mathrm{C}$ anada (along with some $\mathrm{C}$ anadian owned biotechnology companies), is currently arguing for better data protection on research, better enforcement of I PRs and patent term restoration. It makes the point that the U nited States, the European Union and J apan offer patent term restoration of up to five years, in recognition of the time needed for clinical development, and the delays in getting theregulatory approvals. In return for movement on these and other issues the industry is promising to substantially increase investment in research and development $(R \& D)$ with the ultimate goal, of achieving a pharmaceutical innovation ranking of fifth or higher among 0 rganization for Economic Cooperation and D evelopment members. ${ }^{8}$ (Interestingly, there is no firm time commitment put on this promise.)

In order to decide on a future course of action that $C$ anada should take with regard to IPRs as they apply to pharmaceuticals it is useful to review downstream effectsin $C$ anada that resulted from C-22 and C-91. This paper will examine changes to employment, $C$ anada's balance of trade in pharmaceuticals, investment in research and development and finally drug expenditures. Second, it will review the arguments advanced by the pharmaceutical industry in favour of stronger protection for IPRs. Recently, there have been complaints made against $C$ anada at the World Trade O rganization (WTO) regarding pharmaceutical IPRs and these and other contemporary issues are the subject of the third section. The fourth section deals with the second draft text agreement of the FreeTrade Area of theAmericas which will, if implemented, have significant repercussions on pharmaceutical IPR s. Patents distort the marketplace for drugs in a number of ways and the fifth section will briefly touch on half a dozen of these. Finally, the paper concludes with some alternative recommendations on the future of IPRs. 


\section{The environment since 1987}

\section{Changes to employment}

Increases in employment are often cited by the multinational industry as one ben efit of liberalizing the $C$ anadian patent laws. According to figures in the latest publication from $R \times \& D$, the multinational association, employment by member companies went from 14,521 in 1987 to 20,990 in $1999 .{ }^{9}$ However as the Table 1 shows overall employment has increased relatively little in the pharmaceutical industry since 1990.

Table 1: Level of employment in pharmaceutical industry 1990-199910

\begin{tabular}{|c|c|}
\hline Year & $\begin{array}{l}\text { Total number of } \\
\text { employees }\end{array}$ \\
\hline 1990 & 20,426 \\
\hline 1991 & 21,450 \\
\hline 1992 & 21,720 \\
\hline 1993 & 21,046 \\
\hline 1994 & 19,611 \\
\hline 1995 & 19,663 \\
\hline 1996 & 20,701 \\
\hline 1997 & 20,854 \\
\hline 1998 & 21,840 \\
\hline 1999 & 22,306 \\
\hline
\end{tabular}

Some of that change in employment levels has probably comefrom the generic industry. U pto-date figures for the generic industry are not available but from 1990-1995, employment in this sector rose from 1531 to 3631 for an annual increase of just over $27 \% .{ }^{11}$ In the same time period, the number of people employed in the multinational sector went up by $1971,{ }^{12}$ less than the increase for the generic companies and on an annual basis the rate of rise in employment was just $2.5 \%$.

The number of people employed in research and development in the pharmaceutical industry has definitely increased following the restriction and then elimination of compulsory licensing (see Table 2) but the 3580 people employed in this areain 2000 is still considerably short of the 4000 sales representatives working for the multinational pharmaceutical companies in $1995 .{ }^{13}$

\section{Changes in Balance of Trade}

From 1983 to 1987 the Canadian deficit in the trade of pharmaceuticals grew from $\$ 366$ million to $\$ 491$ million. After $C$ anada becamea party to theFreeTradeAgreement (FTA) in 1987 thetrade

Table 2: Changes in R\&D employment, 1987-2002 ${ }^{14}$

\begin{tabular}{|c|c|c|c|c|}
\hline Year & Professionals & Technicians & Other & Total \\
\hline 1987 & 515 & 235 & 240 & 990 \\
\hline 1989 & 835 & 320 & 250 & 1405 \\
\hline 1991 & 1106 & 415 & 314 & 1835 \\
\hline 1993 & 1299 & 591 & 341 & 2231 \\
\hline 1995 & 1392 & 725 & 509 & 2626 \\
\hline 1997 & 1516 & 715 & 508 & 2739 \\
\hline 1999 & 1907 & 762 & 502 & 3171 \\
\hline 2000 & 2115 & 799 & 666 & 3580 \\
\hline
\end{tabular}


deficit went from $\$ 624$ million to $\$ 1464$ million in 1993. By 1996, Canada had the second largest trade deficit out of the 29 countries in the O rganization for Economic Cooperation and D evelopment ${ }^{15}$ and since inception of the $\mathrm{N}$ orth American FreeTradeA greement (N AFTA) (1994) and the WTO (1995) the deficit has gone from $\$ 1612$ million in 1994 to $\$ 4059$ million in 2000.16 17 Figure 1 gives a pictorial presentation of what has happened to the trade deficit in the last five years.

$D$ ramatic as thesefigures are, they do not give a true picture of how much $\mathrm{C}$ anada has come to depend on imports to supply our pharmaceutical needs. Table 3 shows the import penetration of the $C$ anadian domestic market for the three time periods 1983-87, 1988-1993, 1994-2000. In 1983 , imports were $18 \%$ of the Canadian market, in 1993 they were over 34\% and by 2000 over threequarters of the market were made up of imports. M ost imports are fine chemicals that form the activeingredientsin the medications that we use. Therefore, coincident with the change in the $C$ anadian patent laws, there has been a failure to develop a fine chemical industry and pharmaceutical manufacturing has taken on more of an assembly linenaturewhereby ingredients are combined into their final form.

Figure 1: Balance of trade in pharmaceuticals, 1998-2002

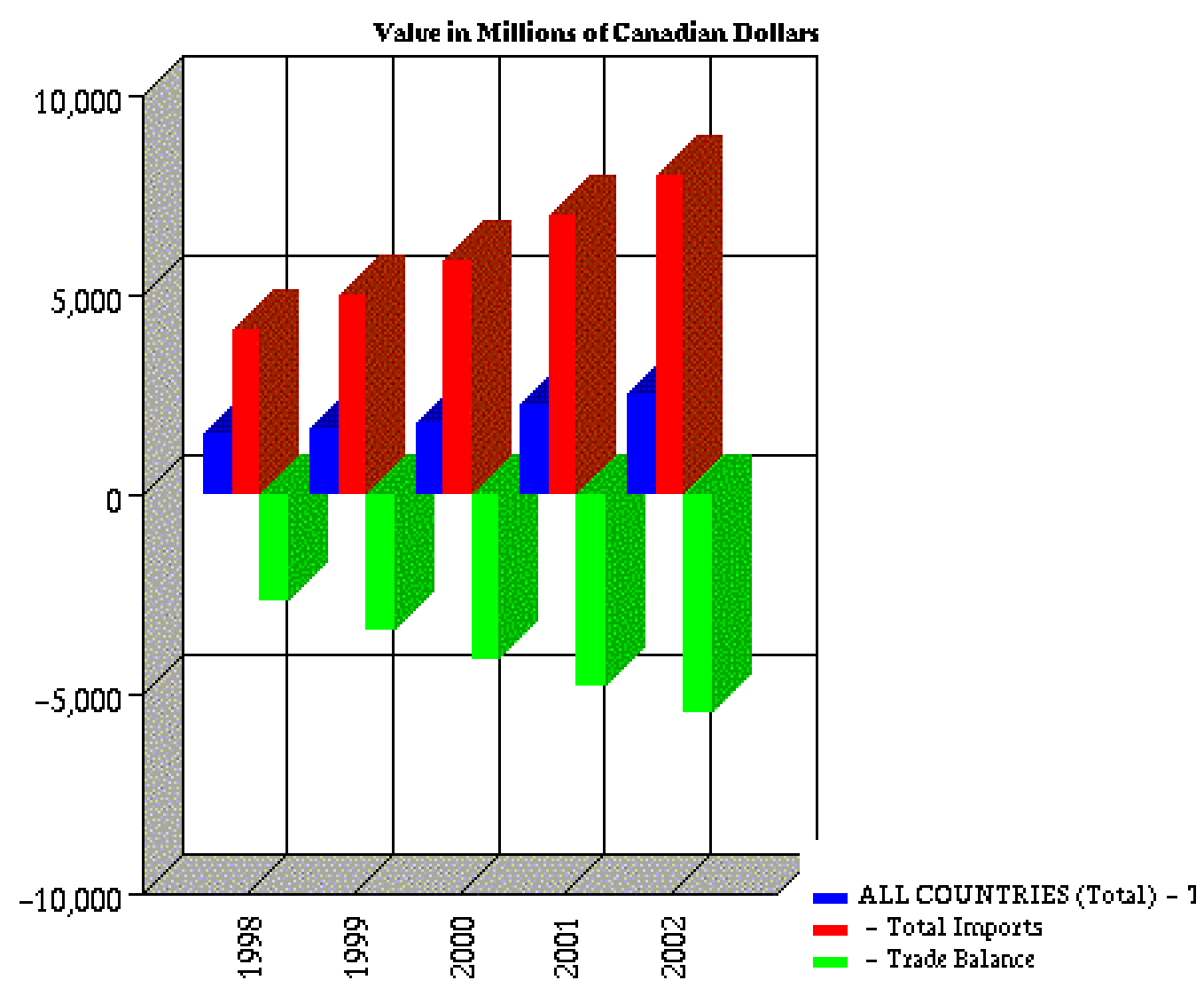

KavaChart Servlets from VE.com 
Table 3: Import penetration of domestic market ${ }^{18}$

\begin{tabular}{|c|c|c|}
\hline Year & $\begin{array}{c}\text { Imports as a percent of } \\
\text { domestic market }\end{array}$ & Percent annual change \\
\hline 1983 & 18.0 & 0.55 \\
\hline 1987 & 20.2 & \\
\hline 1988 & 23.9 & 2.1 \\
\hline 1993 & 34.4 & \\
\hline 1994 & 39.2 & 6.1 \\
\hline 2000 & 75.5 & \\
\hline
\end{tabular}

Figure 2: R\&D as a percent of sales, $1988-2001^{19}$

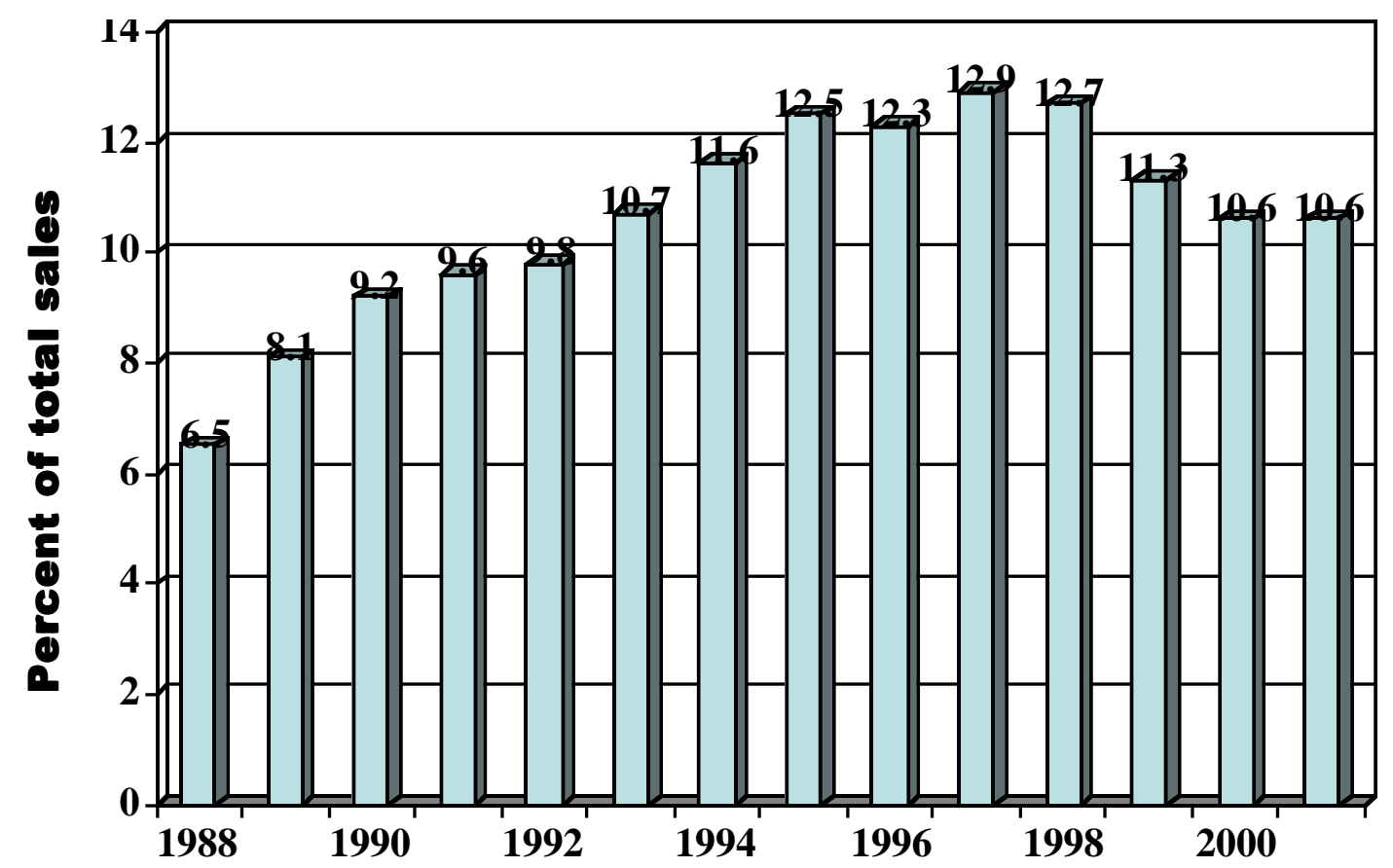

3. Changes in investment in research and development

The pharmaceutical industry made significant investments in $R \& D$ since the changes in $C$ anadian patent laws, but theseadvances, as measured by the $R \& D$ to sales ratio, have been eroding over the past four years. (Figure 2)

Since 1995, C anadian investment in $R \& D$, as a percent of sales, has remained significantly below the levels in six of the seven countries that the Patented M edicine Prices Review Board uses for price comparison purposes (France, Germany, Italy, Sweden, Switzerland, U nited Kingdom, United States). ${ }^{20} \mathrm{~N}$ ot only are we behind these major industrial countries but $C$ anadian $R \& D$ is also lower than most smaller European countries (See Figure 3).

It is not just overall $R \& D$ spending that is of concern. M oresignificantly, basic research and de velopment in $C$ anada has been dropping as a percent of total $R \& D$. In 1990 basic $R \& D$ was $27.2 \%$ of thetotal; by 2001 it wasjust $16.1 \%$. At 
Figure 3: Canadian and European R\&D as a percent of sales

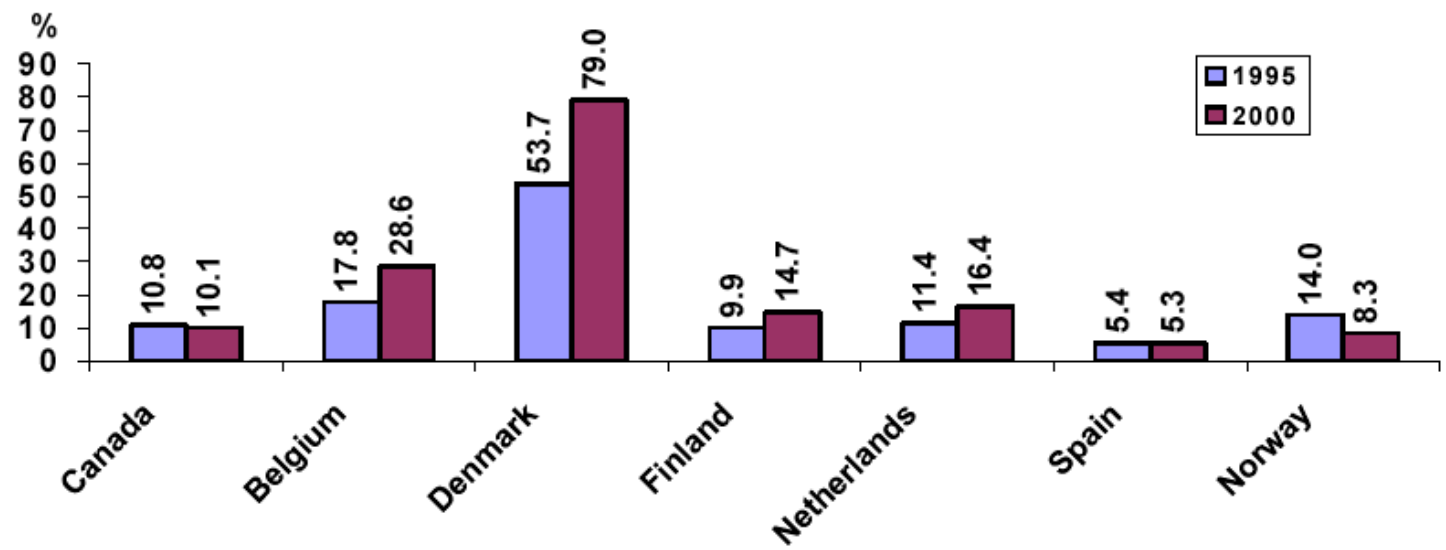

that level $\mathrm{C}$ anada remains substantially behind countries such as the U.K. (24.5\%) and the United States (36\%).

\section{Changes in prescription costs and drug spending}

The Patented M edicine Prices Review Board (PM PRB) was established as part of Bill C -22 to protect consumer interests with powers to limit the introductory prices for new patented drugs and prevent prices for existing patented drugs from rising by more than the rate of inflation. W ithin this context the PM PRB has been a success. Its 2001 report demonstrates that between 1988 to 2000 the rate of inflation for the price of patented medications has risen by just $0.8 \%$ per year; when $\mathrm{C}$ anadian prices are compared to the average of those in seven other countries (France, Germany, Italy, Sweden, Switzerland, the U nited Kingdom, United States) the ratio has dropped from 1.23 in 1987 to just 0.95 in 2001 . H owever, these figures hide a basic failure in the ability of thePM PRB to protect consumers from high prices when it comes to the price they pay for a prescription.

The price of a prescription for non-patented medications increased $2.3 \%$ annually from 1997 to 2001 to a level of $\$ 22.94$ in 2001. O n-the other hand, during the same period patented medications went up at $6.2 \%$ annually to a value of $\$ 84.36$ in $2001 .{ }^{21}$ Physicians have been substituting thesenewer, moreexpensivedrugsfor older, less costly ones leading to the rise in the cost of the average prescription as shown by the fact that between 1997 and 2001 sales of patented medications as a proportion of total sales went from $52.3 \%$ to $65.0 \%$.

The prescribing of newer more expensive drugs in place of older, less expensive, but not necessarily less effective, ones was not something that started in 1987. The practice was well entrenched when $\mathrm{C}$ anada had compulsory licensing. What is different is that after Bill C-91, the prolonged delay in the introduction of generic competitors for these new patented medications. Prior to 1987 generics were coming on the market within five to seven years after the appearance of theoriginator product. Thefirst generic would typically be priced about $25 \%$ lower than the brand name product and when there were three or four generics then the price differential would be $50 \%,{ }^{22}$ In the absence of compulsory licensing the originator product typically is in a monopoly situation for about $10-12$ years. (Thefirst 8 to 10 years of patent life are used up in clinical trials and the drug approval process.) $\mathrm{N}$ ot only has Bill C-91 delayed the entry of generic products by about seven years but also by the time they ap- 
Figure 4: Spending on prescription drugs as a percent of total health spending

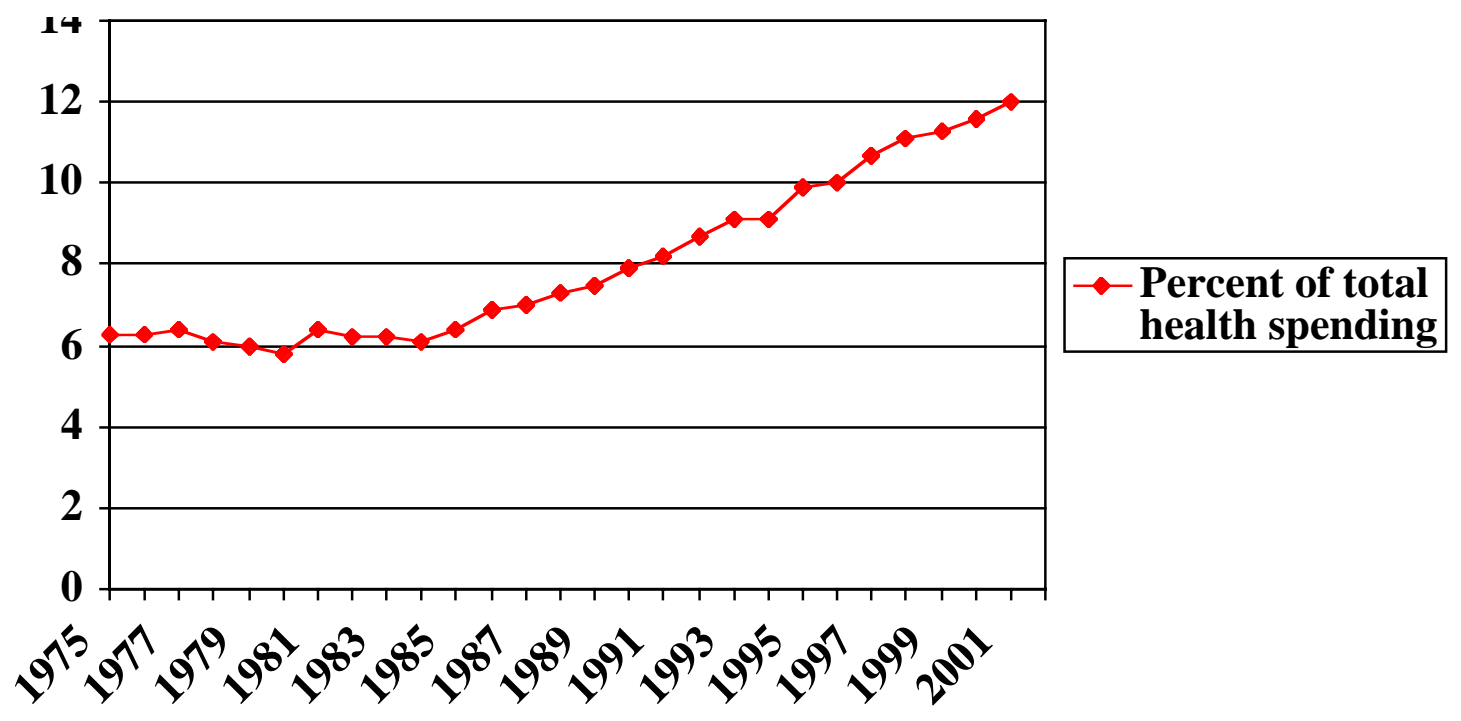

pear sales of the brand namedrug are usually start- scription drugs. Between 1975 and 1987, preing to decline and therefore savings that result scription drugs went from taking up $6.3 \%$ of the from the substitution of generic for brand name health care dollar to $7.0 \%$ for an annual increase products is less.

of $11.5 \%$; in comparison the change between

The delay in the entry of generics is associ- 1987 and 2001 was from $7.0 \%$ to $12.0 \%$, a rise ated with a continual climb in spending on pre of $71 \%$ per year. ${ }^{23}$ (See Figure 4 ). 


\section{Industry's argument for expanded IPR protection}

The crux of the industry's argument for stronger intellectual property rights protection is that it needs the time to recoup its investments in order to be able to afford the costs entailed in the re search and development of new drugs, drugs that may be more expensivethan existing ones but are also more effective and/or more safe.

\section{Profit levels}

If the industry's message is that it needs a longer period of time to recover its investment then a natural starting place is to look at how profitable or unprofitable it has been. Figure 5 shows that at least until the mid 1990s the profit levels in Canada in the pharmaceutical industry were robust compared to those in other "high tech" industries.
There are often arguments that accounting profits are poor measures of the real rate of return on investment in the pharmaceutical industry. This question was investigated in the early 1990s by the $\mathrm{O}$ ffice of Technology Assessment in the United States which concluded that while other methods of calculating profits do lower the differential between the drug makers and other industries, levels are still high enough to have made the industry a relatively lucrative investment. ${ }^{25}$ D espite what the industry regards as inadequate patent protection it was still highly profitable in Canada.

\section{The value of new drugs}

ThePM PRB putsdrugs into one of three categories in order to decide on the highest allowable

Figure 5: Comparative profit levels: return on capital employed, $19966^{24}$

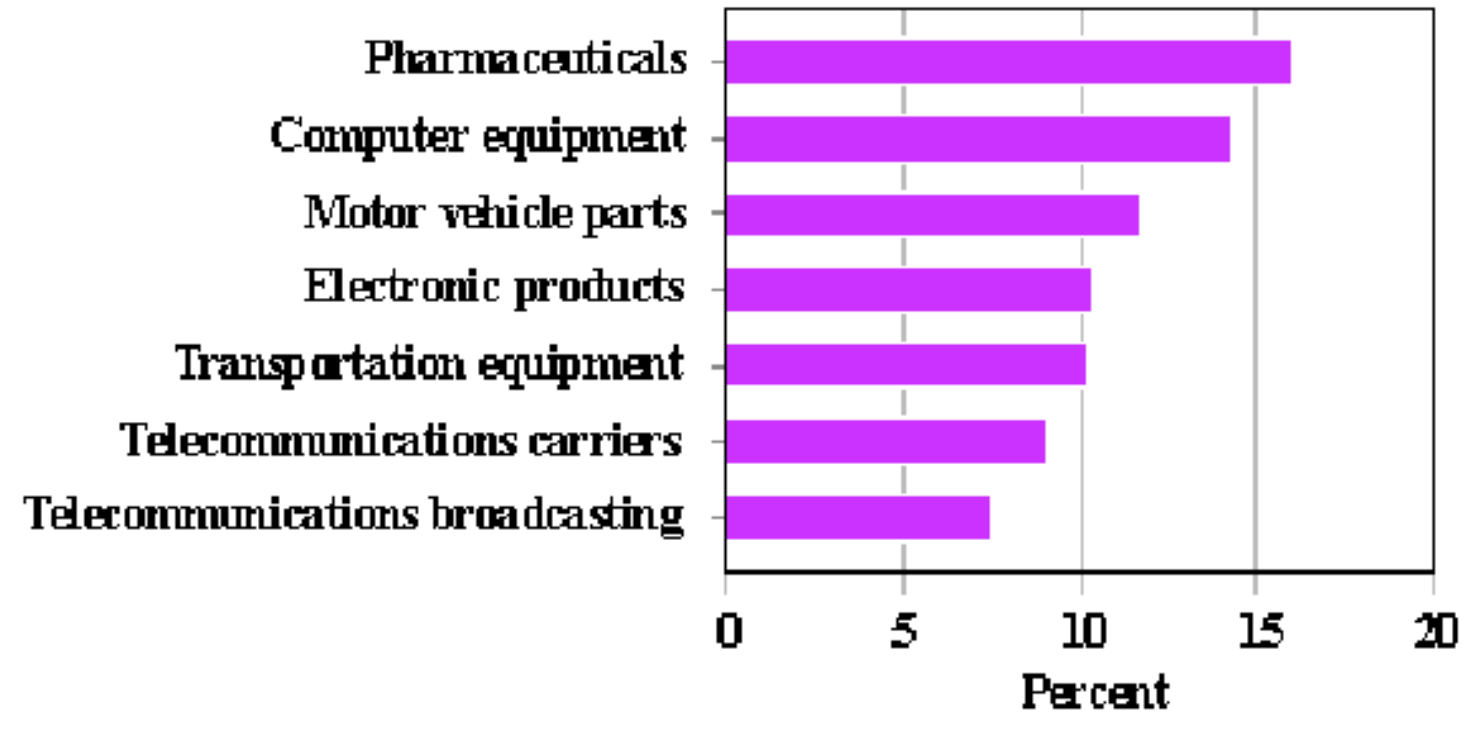

12 Canadian Centre for Policy Alternatives 
price. Category 1 is a line extension (usually a new strength of an existing medication), category 2 is a substantial therapeutic improvement or a breakthrough product (the first medication to treat an illness) and category 3 is a new product or a new dosage form of an existing medicine that provides moderate, little or no improvement over existing medicines. From 1996 to 2000 therewere 455 new patented drugs introduced into $C$ anada. O ut of that total 204 were line extensions, 226 fell into category 3 and 25 or just over $5 \%$ of the total were major improvements or breakthroughs. $^{26}$

The $C$ anadian pharmaceutical industry argues that PM PRB categorizations are merely for determining prices and are not a reflection of actual therapeutic value. But the same critique cannot be leveled against the evaluations made by the French drug bulletin, La revue Prescrire. Ever since 1981 Prescrire has been assessing the value of new drugs and new indications for older drugs on the French market. 0 ver a 21 year period it has looked at 2693 drugs. A mere 7 have been rated a major therapeutic innovation in an area where previously no treatment was available and another 73 were considered products that were important therapeutic innovations but with certain limitations. By far, the majority (1780) were categorized as a superfluous new product that did not add to the clinical possibilities offered by previously available products. ${ }^{27}$

Should $C$ anada be giving the industry extra patent time to develop "metoo" drugs?

\section{The cost of developing new drugs}

The most recent study to look at this question reports that for drugs first tested in humans between 1983 and 1994, the mean cost to bring them to market was U S $\$ 802$ million. ${ }^{28}$ It should be noted that these are not costs that need to be recovered solely through $\mathrm{C}$ anadian sales. $\mathrm{C}$ anada representsabout $2 \%$ of the world pharmaceutical market and therefore a reasonable expectation is that about U S \$16 million should be recouped in Canada.

Beyond the question of how much Canadians should contribute to $R \& D$ costs, there are also fundamental points of dispute around the DiM asi figure. To begin with, the data that DiM asi used were derived from information selfreported by drug companies and there is no independent way to verify this information. Second, the $\$ 802$ million amount represents the costs for only one type of drug- new chemical entities (drugs containing ingredients never marketed before) and excludes drugs that are combinations of previously available medications and reformulations of existing products (e.g., new dosageforms). About $30 \%$ of $R \& D$ expenditures go towards bringing this latter type of drug to market. ${ }^{29} \mathrm{Also}$ any drugs developed with funding from nonindustry sources such as government, hospitals, foundations or medical schools, are excluded. In computing the cost of developing new drugs, it is important to incorporate expenses for products that fail in the development stage. W hile many drugs are withdrawn because of safety reasons or because of lack of effectiveness, at least $20 \%$ of drugs in the development stage are terminated for commercial reasons, that is, because they are not deemed profitable enough. As Frank points out, changes in revenue expectationswould lead to different decisions about drug terminations and would thus change the average cost figure. Finally, over half of the amount that D iM asi calculates is opportunity costs. The estimated outof-pocket cash expenses by the drug companies are $\$ 403$ million.

Before DiM asi's latest study, the pharmaceutical industry was estimating the cost of developing a new drug at about $\$ 500$ million. Public Citizen Congress Watch in the United States looked at the assumptions behind that amount and came up with its own figure of an after-tax 
cash outlay of just $\$ 110$ million..$^{30}$ Public Citizen's calculations have in turn been attacked by the pharmaceutical industry. ${ }^{31} \mathrm{~T}$ he vigorous debate on what the true figure really is, shows that the $\$ 802$ million amount cannot be blindly accepted.

\section{How long is the actual monopoly period?}

The patent term in $\mathrm{C}$ anada is 20 years from the date of filing but the effective monopoly time for brand name drugs is shorter than that owing to the timeit takesfor a product to proceed through the development and regulatory approval stages. $O$ ne of the arguments that $R \times \& D$ advances for increases in the patent protection period is that the effective patent life in $C$ anada is 10 years compared to about 14 in the U.S. and 15 in the EU and Japan. ${ }^{32}$ H ow $R \times \& D$ arrives at the 10 year figure is unclear. Back in 1993 it was also claiming that there was 10 years of effective patent protection $^{33}$ In 1993, drug approval timeswere 1044 days compared to 717 days in 2001 or almost a year longer. ${ }^{34}$ Somehow the decrease of a year did not get reflected in the patent life that $R \times \& D$ presented. It might bepostulated that theoneyear gain in approval timewastaken up by longer clinical testing times but that does not seem to be the case. At most, times from the start of clinical testing to the filing of a submission for approval have increased by 3.5 months during the 1990s. In the U.S. effective patent life for selected drugs is between 13.9-15.4 years. ${ }^{35}$ Some of that time is accounted for by provisions not available in $\mathrm{C}$ anada (patent term restoration $=2.3$ years, pediatric exclusivity $=0.5$ years) and approval times are about 0.8 years faster in the U.S. Using these figures, Canadian effective patent times should be 10.311.8 years, a number roughly consistent with the calculation based on shorter approval times. The Canadian government does not independently collect information on this subject and so in the absence of reliable numbers the industry's argument for longer patent protection becomes much less compelling. 


\section{Current IPR issues}

\section{Recent rulings by the World Trade Organization (WTO)}

O ne of the key elements that went into forming theW TO was theTrade Related Aspects of Intellectual Property Rights (TRIPS) agreement. The impact of the TRIPS agreement is still being felt in C anada. Two separate challenges were launched against $C$ anada in the W TO in recent years. The European Union (EU) complained about a provision in the $C$ anadian patent law that allowed generic drug companies to begin testing, manufacturing and stockpiling drugs for sale before patents expired. W hen $C$ anada changed from a 17 to a 20 year patent term for drugs approved after 0 ct. 1, 1989, the change was not made retroactive. The United States charged that there a group of about 30 drugs which were patented before 0 ct. 1989 should receive an additional 3 years of patent life. (The complaint by the U.S. did not just cover drugs but patents on all products that were granted before 0 ct. 1989 and that were still valid.)

Canada lost the case filed by the U.S. ${ }^{36}$ and theW TO also ruled that generic companies could not stockpile drugs for sale before the patent expired. ${ }^{37}$ Asa result of thesedecisions, in mid 2001 $C$ anadian patent laws were amended once more with the passage of Bill S-17. The extension of the patent term on the 30 drugs is expected to add an estimated $\$ 40$ million to Canada's pre scription drug costs according to the Canadian D rug $M$ anufacturers Association thelobbying arm of the generic industry. ${ }^{38}$ Prohibiting generic com- panies from stockpiling drugs until the patent expires will delay the marketing of generic products for weeks.

\section{Further IPR disputes}

D espite the passage of S-17, and other changes that $C$ anada has made to its patent laws in the wake of the FTA, N AFTA and TRIPS, the Pharmaceutical Research and $M$ anufacturers of America (PhRM A), the peak organization of the U.S. pharmaceutical industry continues to complain that a variety of problems represent significant commercial barriers for its membership. Although PhRMA is concerned about price controls, regulatory delays and restrictions on provincial formulary listings, its main objection remains $C$ anadian protection of IPR. In this regard PhRM A highlightswhat it sees as inadequate protection of registration data (data submitted to show that a drug is safe and effective) and the N otice of Compliance (N OC) "Linkage" Regulations. ${ }^{39}$

N ot only does PhRM A object to these practices because of their economic implications in Canada but it notes that if "a major developed country such as $\mathrm{C}$ anada is failing and continues to fail to comply with the spirit and letter of TRIPS, this will set a negative example for developing countries. $C$ anadian practices that create a dangerous precedent should be addressed before they are adopted in other jurisdictions." A cynical interpretation of this phrase could be that the industry should make Canada "knuckle under" before other countries get "uppity." 


\section{i. Registration data}

To gain marketing approval, generic companies typically demonstrate that their product is bioequivalent to a patented product (that is, that the generic is chemically similar and works the same in the human body) and then rely on the patented product's safety data to earn approval.

$R \times \& D$ notes that $C$ anada protects registration data for 5 years compared to 6 to 10 years in Europe depending on the particular regulatory agency. M oreover, according to $R \times \& D, C$ anada has a "practice of accepting drug submission from generic manufacturers that rely upon the innovator's data within the allotted five year period." $R \times \& D$ contends that policy "effectively undermines the intent of the current data protection provision." (D ata protection will be discussed further in Part IV.)

$R \times \& D$ 's criticisms are echoed by its sister organization in the U.S. Based on PhRM A's reading of Article $39.3 \mathrm{C}$ anada does not offer enough protection for the registration data. PhRM A argues that " $C$ anadian authorities allow parties other than the right holder to effectively gain marketing approval in direct reliance of protected confidential data. This violates T RIPS Article 39.3 as it eliminates the TRIPS requirement to prevent "unfair commercial use" of protected data. We urge the U nited States to movedata protection to the top of the bilateral commercial agenda with Canada." PhRM A's view on data protection was echoed in the 2003 U.S. Trade Representative's (UST R) Special 301 report: "T he problems that originally caused $C$ anada to be placed on the Watch List in 1995 remain largely unresolved. . . C anada does not provide effective data exclusivity protections..." 40

W hat $R \times \& D$ and PhRM A do not point out, is that prolonged data protection periods mean that generic companies haveto redo certain clinical tests to generate information that is already known. $N$ ot only does this delay the appearance of the generic product but it al so wastes resources and subjects patients or volunteers to unnecessary risks in duplicating the safety data.

\section{ii. Notice of compliance "linkage"} regulations

The other major area of IPR where both $R \times \& D$ and PhRM $A$ are aggressively trying to change $C$ anadian policy is with respect to what are termed the Notice of Compliance ( $\mathrm{NOC}$ ) "Linkage" Regulations. Under these regulations, passed in 1993 in the dying days of the Conservativegovernment of Brian $\mathrm{M}$ ulroney and strengthened in 1998 and 1999, thistime under a Liberal government, $\mathrm{H}$ ealth $\mathrm{C}$ anada cannot issuea N O C until the all of the relevant patents on a brand name product have expired. As a result when the generic company submits its application to get a product approved it also sends a N otice of Allegation (N OA) to the patent holder claiming that no patentsarebeing infringed. If the patent holder challenges the N OA then that automatically triggers a 24 month regulatory stay which prevents the $\mathrm{M}$ inister of $\mathrm{H}$ ealth from granting approval to the generic and the matter then may proceed to a court hearing. The stay expires either at the end of the 24 months, when thepatent expiresor when the court case is decided whichever comes first.

PhRM A's position is that while these linkage regulations could provide the "basis for effective protection of pharmaceutical patent owners rights as required under TRIPS and N AFTA . . experience suggests that $\mathrm{H}$ ealth $\mathrm{C}$ anada is taking steps to avoid the necessary application of the regulations." Among other things, PhRM A claims that $\mathrm{H}$ ealth $\mathrm{C}$ anada has been inconsistent in its policies and practices relating to the listing and delisting of brand name companies patents and in requiring generic companies to send a $\mathrm{NOA}_{\text {; }}$ that $\mathrm{H}$ ealth $\mathrm{C}$ anada is continually and systematically limiting further the types of patents that can be listed on the Patent Register; that Canadian courts fail to provide effective recourse in cases 
where an $\mathrm{NOC}$ isissued for an infringing generic medicine; and that ultimately Canadian courts are not applying standards required of them under N AFTA and TRIPS. PhRM A's ultimate conclusion is that the "UST R should attach high priority to remedying this situation."

The effects of these linkage regulations are is a subject of intense disagreement between the generic and brand name companies. The $C$ anadian Generic Pharmaceutical Association (CGPA) claims that "not only is this abuse of Canada's patent regime extremely harmful to $C$ anada's generic pharmaceutical industry, the $C$ anadian public loses out on millions of dollars in savings by having to pay for the higher-priced brand-name version for an extended period of time. The delays caused by these needless court battles have cost $C$ anadians, their governments and private insurers hundreds of millions of dollars." ${ }^{" 1}$ It also says that since the regulations were changed in 1998, the generic companies have won $80 \%$ of the court cases.
$R \times \& D$ counters that these regulationsarenecessary because "generics do not have to concern themselves with a possible interlocutory injunction to prevent infringing sales once an infringing generic product is on the market. Statistics show that this remedy is available in pharmaceutical cases approximately half as often as in other industry patent cases. Indeed, as a result of the inability of pharmaceutical patentees to obtain interlocutory injunctions to prevent the complete destruction of their intellectual property rights and market share, the "linkage" regulations aretheonly means for $\mathrm{C}$ anada to meet its international obligations to provide an effective enforcement mechanism for patents."

$R \times \& D$ also points out that the $80 \%$ success rate for the generic companies translates into 4 out of 5 cases won and presents its own figure showing that generic and patentee "wins" about balance each other out (see Figure 6). The way that $R \times \& D$ calculates the outcomes appears to show a roughly equal split in wins. H owever, an

Figure 6: Outcome of linkage disputes since 1993

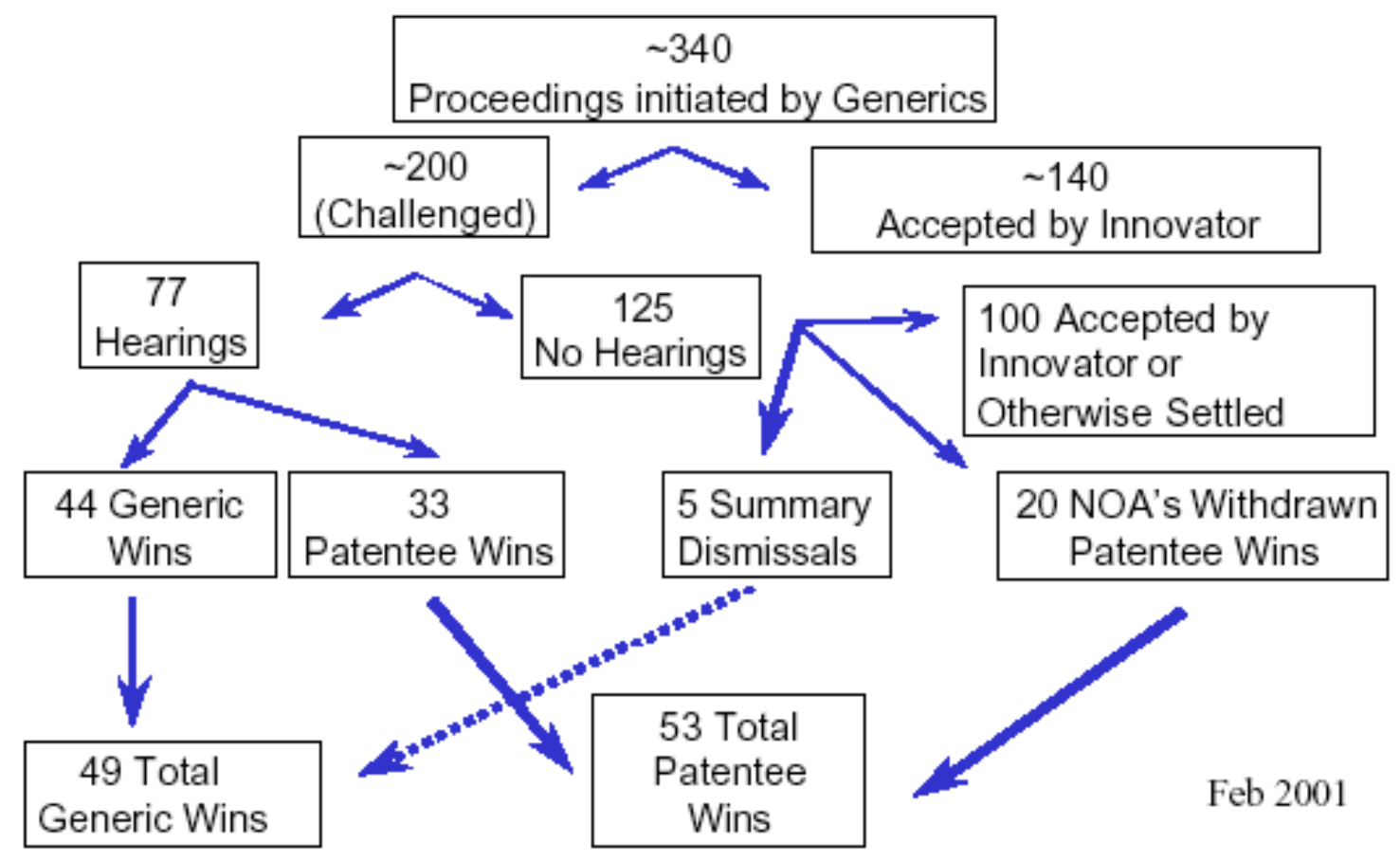


examination of this figure shows that the brand namecompanies arealso not above playing around with numbers. There are 125 cases where there was no hearing, in 20 cases where the N OA was withdrawn this is counted as a win for the patentee but the 100 cases where the innovator either accepted the N OA or the case was otherwise settled are not counted as wins for the generic.

A second area of contention is the use of multiple patents to delay the appearance of a generic product. The CGPA maintains that the brand name companies continually list new patents on a product, each of which can trigger a new N OA and an additional stay on the appearance of a generic. In this way, competition is delayed.

$N$ aturally, the brand name companies dispute this interpretation. Their position is that there is always ongoing research into drugs and that it is natural that new patents will be filed, reflecting improvements such as moving from a three pill a day regimen to a once a day regimen. The multinationals say that $95 \%$ of cases all subsequent patents will be issued within 10 years of the initial patent and therefore all of the patents may be addressed in the same linkage proceeding. But if the effective patent life is only 10 years, as $R \times \& D$ claims it is, then new patents are being filed as old ones expire. Even if patents are a couple of years longer then there can still be overlapping 24 month stays depending on when the generic company files for a N O C. According to $R \times \& D$ in that situation all the generic companies have to do is market the older version of the product on expiry of the original patent. All of this is true but it ignores the fact that the main reason for launching a new formulation of a drug is to switch doctors to that version before a generic is availableto undercut the market for the generic; something that brand name companies spend millions of advertising dollars doing.

Finally, the only other country where there is a stay in the marketing of generics until patent issues are settled is the U.S. There drug makers can receive an automatic injunction of up to 30 months. In 0 ctober 2002, reacting to allegations of abuse of these injunctions, President George Bush announced that he would rewrite patent regulations to limit the brand name companies to a single 30 month injunction on any single drug ending the practice of filing multiple overlapping claims of patent infringement. ${ }^{42}$ 


\section{The Free Trade Area of the Americas (FTAA) Agreement}

N egotiations are ongoing for a free trade agree ment that would include all 34 of the countries of N orth, Central and South American and the Caribbean, except for Cuba. Although most of the draft text is still bracketed, meaning that it is still subject to negotiations there are elements in the text that, if enacted, would markedly affect IPRs in C anada.

\section{Extension of patent term}

Under Section 5, Article8.2 (Part II) patent owners would be able to receive additional patent life if it took longer than 4 years to grant a patent. ${ }^{43}$ H owever, in the case at the W TO against $C$ anada filed by the EU, the panel ruled that this type of claim for an extension of the patent term is not a "legitimate interest" within the meaning of the TRIPS agreement. ${ }^{44}$ Although the draft FTAA agreement does not mention extending patents to take into account the regulatory approval time, it is clear from this interpretation that this is also something that is not required by the TRIPS agreement.

\section{Data protection}

Section 10, Article 1.2 establishes a minimum of 5 years of data protection. N AFTA al ready mandates a 5 year period of registration data protection so on the surface what is being proposed in the FTAA does not appear to be any more onerous than the current requirements. H owever, the Federal Court of Appeal has put a specific inter- pretation on N AFTA Article 1711 on "Trade Se crets." The court held that " $W$ hen a generic manufacturer files an Abbreviated $\mathrm{N}$ ew $\mathrm{D}$ rug Submission (ANDS), the safety and effectiveness of the generic product may be demonstrated by showing that the product is the pharmaceutical and bioequivalent of the innovator's product. If the generic manufacturer is able to do so solely by comparing its product with the innovator's product which is being publicly marketed, the $M$ inister will not have to examine or rely upon confidential information filed as part of the innovator's $N$ ew D rug Submission (N D S). In such case, theminimum fiveyear market protection referred to in the regulation will not apply." ${ }^{45}$ It is not clear that the same interpretation would be applied to theFTAA agreement articleand thereforeits adoption could lead to a restriction in the use of registration data with the consequences discussed above.

\section{Linkage requirements}

Section 10, Article 1.5(a) (Part II) would effectively impose the equivalent of NOC Linkage Regulations on all signatories to the FTAA. Right now, the linkage regulations are a $C$ anadian re quirement and can be altered by the federal government. Imbedding them in the FTAA would mean that any move by $C$ anada to unilaterally weaken or abolish them could be challenged in a trade tribunal under the FTAA. O nce part of the FTAA linkage provisions could only be changed by unanimous agreement by all parties, something that the U.S. is unlikely to ever accede to. 


\section{Compulsory licensing}

Finally, Section 5, Article 5.1(a) (Part II) would imposemorestringent conditionsthan theTRIPS Agreement requires for the granting of compulsory licenses. The W TO M inisterial D eclaration (D oha D eclaration) on theT RIPS Agreement and Public $\mathrm{H}$ ealth states "Each member has the right to grant compulsory licenses and the freedom to determine the grounds upon which such licenses are granted. ${ }^{\prime 46}$ At present, the $C$ anadian government has decided to forgo the option of using compulsory licensing but should it want to reverse that decision at some point in the future it would find its options severely limited by the proposed FTAA agreement. Under the current text, compulsory licenses would be restricted to three situations: "for public non-commercial purposes or in situations of a declared national emergency or other situations of extreme urgency." 


\section{How IPRs distort the pharmaceutical marketplace}

There are significant economic costs to $C$ anada associated with using the IPR system be they in higher drug spending, more reliance on imports or a divergence of the $R \& D$ budget away from basic research. This section takes a closer look at other ways in which the patent system warps the pharmaceutical marketplace.

As we saw earlier, the large majority of drugs produced through research lead by the patent incentive do not represent any significant therapeutic advances. Industry largely engages in $R \& D$ of products that are aimed at carving out a share of a lucrative market. The result is drugs that are essentially minor variations on existing medications, for example, additions to the statin group of drugs for lowering cholesterol. Since most drugs offer little or no therapeutic advantage over existing remedies then it stands to reason that most of the money spent on $R \& D$ is going into products that will build market sharenot products that will necessarily result in significantly better health outcomes.

Baker and $\mathrm{C}$ hatani itemize an additional five ways that patent protection leads to wasteful rent seeking behaviour by pharmaceutical companies. ${ }^{47}$ In order to capture market sharefor their copycat drugs companies spend about $\$ 1.7$ billion in promotion in $\mathrm{C}$ anada and more than 10 times that amount in the U.S. ${ }^{48}$ In 2000 in Canada M erck spent over $\$ 6.25$ million promoting just onedrug, Vioxx. 0 ver 1 million samples were left behind in doctors' offices and there were over 1000 pages of journal ads. ${ }^{49}$

Gaining a competitive edge on rival firms leads to a restriction in sharing of research results and delays in publication of findings because of commercial concerns. Twenty-seven per cent of faculty in university life science academic departments who received industry support delayed publication of their resultsfor morethan 6 months compared to $17 \%$ without such support. ${ }^{50}$ Eightyone percent of life science companies with relationships with academic institutions reported keeping results secret for longer than was necessary to obtain a patent. ${ }^{51}$ Communication is the lifeblood of science and if it is impeded so is scientific research. Without knowing what others are doing scientists may beneedlessly repeating work.

There are the direct legal costs associated with filing and protecting patents and theindirect costs that result from successful efforts such as "evergreening" that stall the marketing of generic drugs. When the $\mathrm{C}$ anadian Coordinating $\mathrm{O}$ ffice for H ealth Technology Assessment (CCOHTA) was about to release a report saying that all of the different drugs in the statin group were equivalent, Bristol-M yers Squibb (BM S), makers of one of these drugs, objected to the release of the re port and went to court to block its publication. The case was eventually thrown out but not before CCOHTA spent $13 \%$ of its annual budget defending itself. ${ }^{52}$ Lawyers fees for BM $S$ are not known but must also have been substantial. A report prepared for the $C$ anadian $G$ eneric Pharmaceutical Association looked at a group of 34 generic products estimated that each day of delay in reaching the market was associated with a cost of almost $\$ 5500$ per product. ${ }^{53}$

In the U nited States the pharmaceutical industry employs over 600 lobbyists and spent US $\$ 78.1$ million in 2001 partly to ensure that its view about IPRs was heard by politicians. ${ }^{54}$ Industry in C anada is also into heavy political lobbying. Deputy-Prime M inister John M anley in 
his run for the leadership of the Liberal party has received tens of thousands of dollars in donations from a group of 6 pharmaceutical companies plus $R \times \& D$. According to another Liberal parliamentarian, $M$ anley is a key backer of the brand-name pharmaceutical industry'sinterests in cabinet discussions and is "part of the Praetorian Guard of status quo on high drug prices." 55

In the U nited States, pharmaceutical companies fund a variety of consumers' and patients' groups which then appear to independently support positions favourable to the industry. D uring the 2002 U.S. elections the United Seniors Association received over US $\$ 10$ million from the drug companies to spend on television advertisements. In the 2000 American elections Citizens for Better M edicare, at its peak, was spending more than US \$1 million a week on advertisements all of it paid for by PhRM A, the industry trade association. ${ }^{56}$ 


\section{Where does Canada go from here?}

If we accept the argument that intellectual property rights are necessary for the development of new pharmaceuticals, and for themoment wewill, then the question becomes how much patent time is required to ensure that companies continue to invest in new drug $R \& D$. In order to estimate the appropriate period of patent protection we need to know the actual cost of bringing a new drug to market. Recall that the DiM asi figure comes from self-reported industry data. The only attempt to engage in an independent examination of industry information came during the 1970sand early 1980swhen the G eneral Accounting 0 ffice (GAO), the investigative arm of the U.S. Congress, sought financial data that would allow it to estimate research, development, marketing, promotion, and distribution costs for individual products. The drug companies objected on the grounds that the confidentiality of their cost and other data could not be protected. Ultimately the dispute went to the U.S. Supreme Court which ruled that the GAO was not authorized to collect this type of information. The end result is that we have to rely on the drug companies to accurately report their $R \& D$ costs. Both the former editor-in-chief of the $\mathrm{N}$ ew England Journal of M edicine and a staff report from the U.S. Senate Special Committee on Aging believe that some of the research and development budget is for marketing research; ${ }^{57} 58$ moreover the Senate report charges that postmarketing studies aimed at promoting unapproved uses of drugs are disguised as research. $\mathrm{H}$ ow is the $\mathrm{C}$ anadian government going to make decisions without having the proper information?
A more fundamental question is whether or not the patent system is even necessary. A 2002 report from the $C$ enter for Economic and Policy Research argues that as research costs rise, they will reach a point where public/not-for-profit funding will be more efficient than patent supported research. "T he reason for this is that patents effectively allow private firms to charge an excise tax - the mark-up allowed by the patent monopoly - on prescription drugs. Theeconomic distortions associated with such a tax are proportional to the square of the mark-up. Therefore, if drug companies have to charge twice as high a mark-up in order to cover their research costs, then the size of the economic distortions will be multiplied fourfold. This means that even if patent supported research is somewhat more efficient than public/ non-profit supported research on a dollar for dollar basis, at some point the distortions created by the patent mark-up must eventually offset this greater efficiency."

Baker and Chatani go on to show that the amount of money that would be needed were all of pharmaceutical $R \& D$ to be funded through the public system would be more than offset by the lower drugs prices that would result from the absence of the patent system. Their numbers come from the American context and may or may not apply equally well in C anada but they should serve to start a debate about whether or not the patent system is the best way to fund pharmaceutical $R \& D$. 


\section{References}

1 H ouse of Commons, Standing Committee on Industry. Review of Section 14 of the Patent Act Amendment 1992 (Chapter 2, Statutes of Canada, 1993). O ttawa, April 1997.

2 Commission on theFuture of $\mathrm{H}$ ealth Carein Canada. Building on values: the future of health care in Canada - final report. O ttawa, 2003.

3 M cGregor G. "Take two patents . . . and call me next year: the never-ending war to redraw $C$ anada's arcane drug patent laws." Ottawa Citizen, January 20, 2002:C3.

4 H ouse of Commons, Standing Committee on Industry, Science and Technology. Committee Evidence Number 80. M ay 7, 2002. http:// www.parl.gc.ca/InfoC omD oc/37/1/IN ST/M eetings/Evidence/instev80-e.htm. Accessed $28 \mathrm{M}$ ay 2003.

5 "Industry committee votes 10-1 to hold review of N OC regulations." Ottawa Citizen, June 12, 2002.

6 M cG regor G. "Victory for big drug makers: M Ps shelve review of policy that helps keep generic rivals off the market." Ottawa Citizen, April 1, 2003.

7 Elston MJ. Speech to the British Columbia Business Council linking healthcare policy with the economy. January 30, 2003. Available at: http:// www.canadapharma.org/M edia_Centre/Speeches/ Lan30-03.html. Accessed 11 February 2003.

8 Canada's innovative pharmaceutical industry: a new deal for Canadians. 24 September 2002. Available at: http://www.canadapharma.org/M edia_C entrel $\mathrm{N}$ ews Releases/2002/Sept24-02_e.html. Accessed 2 $M$ arch 2003.

9 C anada's Research-Based Pharmaceutical Companies. 2000-2001 annual review. I believe. 0 ttawa: $\mathrm{R} \times \& \mathrm{D}$, nd.

10 Industry Canada. Pharmaceutical and medicine manufacturing. Availableat: $h \mathrm{ttp}: / /$ strategis.ic.gc.cal canadian_industry_statistics/cis.nsf/idE/ cis32541defE.html. Accessed 31 January 2003.

11 Duncan R, Blaker D. Trends in the pharmaceutical industry in Canada in the post 1987 environment. Consumer and Corporate Affairs $\mathrm{C}$ anada, nd.
12 Pharmaceutical $M$ anufacturers Association of Canada. 1996-1997 annual review. A decade of achievement. 0 ttawa: PM AC, nd.

13 Jewesson $\mathrm{P}, \mathrm{H}$ erar $\mathrm{S}$. "Activities of pharmaceutical industry representatives at a major teaching hospital." Canadian Journal of Hospital Pharmacy 1996;49:256-60.

14 Statistics $C$ anada. Industrial research and development statistics, various years. Catalogue N o. 88-202.

15 Jacobzone $S$. Pharmaceutical policies in OECD countries: reconciling social and industrial goals. Labour M arket and Social Policy Occasional Papers N o. 40. Paris: OECD, 2000. www.olis.oecd.org/ OLIS/2000D OC.N SF/LIN KT O/DEELSA-ELSAWD (2000)1.

16 Industry Canada. Sector competitiveness frameworks. Pharmaceutical industry: part 1-overview and prospect. 0 ttawa: Industry C anada, 1997 (cat. no. C21-22/21-1-1997).

17 Trade $\mathrm{D}$ ata $\mathrm{O}$ nline. Canadian trade by industrySIC codes. strategis.ic.gc.ca/sc_mrkti/tdst/tdo/ tdo.php\#tag. Accessed $2 \mathrm{M}$ arch 2003.

18 Industry $\mathrm{C}$ anada. Sector competitiveness frameworks. Pharmaceutical industry: part 1-overview and prospect. 0 ttawa: Industry Canada, 1997 (cat. no. C21-22/21-1-1997).

19 Patented M edicine Prices Review Board. Annual re port 2001. 0 ttawa, 2002.

20 Patented M edicine Prices Review Board. A comparison of pharmaceutical research and devel opment spending. PM PRB Study Series S-0217, D ecember 2002.

21 Green Shield Report, Toronto, 2002.

22 Lexchin J. "The effect of generic competition on the price of prescription drugs in the Province of O ntario." CM AJ 1993;148:35-8.

23 Canadian Institute for $\mathrm{H}$ ealth I nformation. N ational health expendituretrends, 1975-2001, report: executive summary. $\mathrm{O}$ ttawa: $\mathrm{CIH} \mathrm{I,} 2001$.

24 Statistics $\mathrm{C}$ anada. Financial performance indicators for $C$ anadian business $C$ atalogueN 0. 61F0058XPE, 1996.

25 U.S. C ongress, O ffice of Technology Assessment. Pharmaceutical $R \& D$ : costs, risks and rewards. OTA- 
H-522. Washington, D.C.: Government Printing O ffice, February 1993.

26 Patented M edicine Prices Review Board. Annual re port 2000. 0 ttawa, 2001.

27 D rugs in 2001: a number of ruses unveiled. Prescrire International 2002;11:58-60.

28 D iM asi JA, $H$ ansen RW, G rabowski H G. "The price of innovation: new estimates of drug development costs." Journal of $\mathrm{H}$ ealth Economics2003;22:151-85.

29 Frank RG. "N ew estimates of drug development costs." Journal of $\mathrm{H}$ ealth Economics2003;22:325-30.

30 Public Citizen Congress Watch. $R \times R \& D$ myths: the case against the drug industrys $R \& D$ "scare card." Washington D.C., July 2001.

31 Ernst\& Young LLP. Pharmaceutical industry R\&D costs: key findings about the Public Citizen report. Washington D.C., August 8, 2001.

$32 \quad R \times \&$ D. S-17: a necessary first step to bring Canada's patent act to internationally competitive standards. $A$ brief to the H ouse of Commons Standing Committee on Industry, Science and Technology. 0 ttawa, M ay 29, 2001.

33 Pharmaceutical $M$ anufacturers Association of C anada. 1988-1993: a fiveyear report on the Canadian brand-name pharmaceutical industry. 0 ttawa, 1993.

$34 \quad \mathrm{R} \times \&$ D. D rugapproval timesin Canada 2001. http:/ /www.canadapharma.org/Industry Publications/ Fact Sheets). Accessed 24 M ay 2003.

35 H unt M I. Prescription drugsand intellectual property protection: finding the right balancebetween accessand innovation. Washington, D .C.N ational Institute for $\mathrm{H}$ ealth $\mathrm{C}$ are $\mathrm{M}$ anagement, August 2000.

36 M acKinnon M. "W TO rejects patent law appeal." Globe and M ail September 19, 2000:B10.

37 Scoffield H. "WTO upholds drug patent rule." Globe and $M$ ail $M$ arch 18, 2000:B3.

38 "Battle to repeal automatic injunctions against generic drug approvals moves to the fall." CDMA Viewpoint Summer 2001:1,6.

39 PhRM A. 2003 PhRM A Special 301 submission: Canada. http://www.phrma.org/international/resources/03.03.2003.349.cfm. Accessed 24 M ay 2003.

40 U nited StatesTrade Representative. Intellectual property - 2003 Special 301 report - watch list. http:// www.ustr.gov/reports/2003/special301-wl.htm. Accessed 24 M ay 2003.

41 C anadian Generic Pharmaceutical Association. The patented medicines (notice of compliance) regulations. http://www.cdma-acfpp.org/en/issues federal/ noc regulations.html. Accessed 15 January 2003.

$42 \mathrm{M} \mathrm{g} \overline{\mathrm{G}}$ regor G. "U.S. plan leaves $\mathrm{C}$ anada behind on drugs Bush will eliminate rules that help drug giants keep prices high." 0 ttawa Citizen, 220 ctober 2002.

43 FTAA - Free trade area of the Americas. D raft agree ment: chapter on intellectual property rights. 1 N ovember 2002, FTAA.T N C/w133/Rev.2.

44 World Trade $O$ rganization. Canada - patent protection of pharmaceutical products. Complaint by the European Communities and their member states. Report of the panel. 17 M arch 2000, WT/D S114/ $\mathrm{R}$.

45 Correa C. Protection of data submitted for the regis tration of pharmaceuticals implementing the standards of theT RIPS agreement. G eneva: South Centre, 2002.

46 World Trade O rganization, M inisterial C onference, Fourth Session. D eclaration on the T RIPS agreement and public health. 14 November 2001, WT/ M IN (01)/DEC/W/2.

47 Baker D, Chatani N. Promoting good ideas on drugs: are patents the best way? The relative efficiency of patent and public support for bio-medical research. Washington D.C.: Center for Economic and Policy Re search Briefing Paper, 0 ctober 2002.

48 IM S H ealth. Total U.S. promotional spending by type, 2001. http://www.imshealth.com/public/structure/ dispcontent/1,2779,1343-1343-144077,00.html. Accessed 190 ctober 2002.

49 CBC D isclosure, Targeting doctors. G raph: top 50 drugs by total promotional dollars. Available at www.cbc.ca/disclosure/archives/0103_pharm/ resources.html. Accessed M arch 30, 2002.

50 Blumenthal D, Campbell EG, Anderson MS, Causino N, Louis KS. "Withholding research re sults in academic life science. Evidence from a national survey of faculty." JAM A 1997;277:1224-8.

51 Blumenthal D, Campbell EG, Anderson M S, Causino N, Louis KS. "Withholding research re sults in academic life science. Evidence from a national survey of faculty." JAM A 1997;277:1224-8.

52 Hemminki $E, H$ ailey $D$, Koivusalo $M$. "The courts- a challenge to health technology assessment." Science 1999;285:203-4.

53 Anderson M, Parent K. Timely accessto generic drugs: issues for health policy in Canada. Kingston: Q ueen's University, 2001. 
Public Citizen C ongress Watch. The other drug war II: drug companies usean army of 623 lobbyists to keep profits up. Washington D.C., June 2002.

55 Clark C, M cC arthy S. "D rug-company donations to $M$ anley spark controversy." G lobeand $M$ ail, $M$ ay 14, 2003. http://www.globeandmail.com/servlet/ story/RT G AM ...030514.umanl0514/BN Story/National/?query=manley. Accessed $17 \mathrm{M}$ ay 2003.

$56 \mathrm{H}$ ogan $\mathrm{B}$. "Pulling strings from afar: drug industry finances nonprofit groups that claim to speak for older Americans." AARP Bulletin Online, February
2003. http://www.aarp.org/bulletin/departments/ 2003/consumer/0205 consumer 2.html. Accessed 18 February 2003.

57 Angell M. "The pharmaceutical industry- to whom is it accountable?" N ew England Journal of M edicine 2000;342:1902-4.

58 U nited States Senate, Special Committee on Aging, Staff Report. Thedrug manufacturingindustry: a pre scription for profits. Washington, D.C.: U.S. Government Printing O ffice, 1991, Serial N o. 102-F. 